\title{
Hampshire Women as Landholders: Common Law Mediated by Manorial Custom
}

\author{
S Y L VIA SEELIGER
}

The traditional idea of a landowner is inextricably bound up with concepts of maleness. The most frequently used word for a landowner is simply 'landlord', with the corresponding feminine form 'landlady' carrying quite different connotations. The law with regard to inheritance and marriage lends weight to this interpretation, since common law, until the mid-nineteenth century, decreed that married women could not own property or make contracts as individuals, in theory leaving only spinsters and widows as potential landowners. Yet scrutiny of manorial, enclosure, tithe and land tax documentation reveals that women commonly held land either as owners or occupiers.

The research which has been carried out on the position of women as regards real property has largely concentrated on women of the aristocratic and gentry classes. ${ }^{1}$ Less has been done on the situation of women of the 'peasant' or subsistence class, particularly on the basis of a region or locality. This paper concerns itself with women who were 'peasant' landholders in the county of Hampshire during the transition period of the centuries before the passing of the Married Women's Property Acts in 1870 and 1882 . It focuses particularly on manorial and tithe documentation during the period c.1650 to c.1900 in order to understand how the strictures of the common law were dealt with by customary law in relation to women's landholding, with particular attention being given to the manors held by the Dean and Chapter of Winchester, and by aristocratic owners. ${ }^{2}$ Court rolls, and court books, associated surveys, rent books and particulars, dealing as they do with land transactions and holdings on a comprehensive scale, represent an invaluable resource where the day-to-day experience of landholding by women can be assessed. The Tithe Apportionments offer the advantages of representing the spatial pattern of landholding in an area; of forming a benchmark in that they were compiled within a compact time-span; and of distinguishing between owners and occupiers, therefore allowing a fuller understanding of women's status as landholders. 
The common law as applied to marriage, property and inheritance offered women no real protection and could indeed be described as punitive, in that women who married lost control of their property to their husbands. Some amelioration of the harshness of common law was offered by the equity courts which sought not to change the law, but to avoid its consequences by 'providing ad hoc remedies in individual cases', ${ }^{3}$ and the various kinds of marriage settlements cited by Amy Erickson as being used at all levels of society were often enforced in Chancery. ${ }^{4}$ Ecclesiastical courts were generally involved in matters of probate and therefore exercised influence over widows' entitlements, and until the seventeenth century upheld women's one-third share of husbands' property as an absolute minimum. Perhaps less well known is the protection that customary law, enforced through the manorial courts, could offer women landholders, and this paper examines the moderation of common law rules through the customary structure.

Eleanor Searle's examination of the workings of merchet in medieval England ${ }^{5}$ indicates that the issue of women's marriage and its consequences for inheritance of land in all classes formed a fundamental concern for the barons and lords. Solutions to the age old problem (experienced by all categories of landholders) of how to provide a living for offspring, including daughters, under primogeniture were made more difficult because of 'coverture', which allowed land to be lost to the family. This legal provision has been defined by Baker as a state in which a married woman's 'very being or legal existence ... is suspended during the marriage, or at least is incorporated and consolidated into that of the husband'. ${ }^{6}$ Therefore, the lord had a crucial interest in any man taken as a husband by a woman under his jurisdiction, because the rules of coverture would dictate that the husband would become the new tenant, responsible at first for providing the necessary services, and later, for a money payment for the tenement.

It is clear from the evidence cited by Searle that women were held to be suitable heirs of land. Searle takes the commonsense view that 'any daughter of any vassal was potentially an heiress ... in a period of short life expectancy'. A woman's dowry, whether in land or chattels, was considered to be her own property, and of interest to the lord as a way of increasing his revenue by means of the use of licences to generate fines, as well as to check on the suitability of suitors as potential male tenants. It also provided a way of preventing over-generous dowries from harming the economic prospects of the siblings of the potential bride. Searle illustrates that even very young girls who were heiresses had their interests safeguarded, in one case by forcing another tenant to look after her land until she was ready to inherit, which she did at her marriage on payment of an entry fine.

The work of Franklin on the liberation of peasant widows before the Black Death indicates that women were a significant force in landholding in medieval times. ${ }^{8}$ Franklin notes that: 'deceased male tenants' holdings frequently passed to widows rather than directly to sons, which explains why women commonly formed a substantial proportion of tenants. They played an important role in the workings of inheritance, and on some estates their remarriages removed holdings permanently outside the family.' This is the principal reason why widows' holdings became tenable only for life or for widowhood. Where widows took up their late husbands' holdings, it is clear that they were able to exercise a degree of independence hitherto unknown to them as married women. Those 
widows who did not remarry are quoted by Franklin as having formed 14.8 per cent of tenants in manorial surveys by J.C. Russell, 12.1 per cent by J.Z. Titow, between 8 and 10 per cent by J.F. Willard, and in Gloucestershire the proportion was 10 per cent in 1327. ${ }^{9}$

It seems that by the seventeenth century, in Hampshire at least, widows of customary, copyhold and leasehold tenants were generally admitted to the whole of their husbands' holdings for life as a matter of course, through the workings of 'free bench', provided they did not remarry. The next heir at the widow's death would most likely be the eldest son of the marriage, though there are also cases where the widow was granted an annuity and rooms in the family house.

Amy Louise Erickson has examined the property ownership of women in the period 1580 to 1720 , and she has inevitably highlighted the gap between legal theory and practice, although she has concentrated on wills, inventories and probate accounts. ${ }^{10}$ These deal principally with 'moveables', the main form of property held by women, and allows her to deal very thoroughly with this kind of ownership. Erickson's work on marriage settlements in early modern England details the workings of separate estate, which was not defensible in common law, only in equity." This allowed women to preserve some property, especially where there were dependent children, and would allow a married woman to make a will. What we do not generally know is what proportions of land were in the hands of three categories of women (spinsters, married women and widows) and if there is any measurable difference in the way women landholders dealt with their land.

The most 'invisible' category of female landholder is the married woman, because of coverture. Until the passing of the Married Women's Property Act in 1882, she could not acquire, hold or dispose of real or personal property. This provision had been the servant of the principle of primogeniture, which ensured that estates could pass whole from generation to generation. Under primogeniture, the eldest son inherited the family land and other kinds of financial provision were made for his siblings. The injustice of coverture was recognised even in a traditional, patriarchal society, and it is clear that primogeniture was not favoured by all classes. Indeed, it only applied to freehold and some kinds of copyhold land. Thirsk suggested in her paper on the common fields that it was never popular with the peasantry, who would have had to provide a living for all offspring and could not easily do this through primogeniture, which she suggests was therefore generally confined to the aristocracy. ${ }^{12}$ Redress for married women was possible through the ecclesiastical and equity courts (though the latter were too expensive for ordinary women), and increasingly through marriage settlements. However, manorial custom was far more practical and accessible, in that it ordered life in a way that provided the opportunity for all women to gain a livelihood, regardless of marital status.

In periods when marriage was thought of as more of an economic arrangement than it is now, special care had to be taken to provide a living for a married woman when she became a widow, especially if there were dependant children. In cases of intestacy, land and other property would descend through the principle of primogeniture, but widows were entitled to approximately one third of their husband's estate, a right known as dower in the case of freehold land. This might take the form of a life interest in his 
land, accommodation in the marital home when the children took it over, or a cash annuity charged on the land. Land often did pass directly to the widow in preference to the son or sons and, of course, there were inevitably many cases when there were only daughters to inherit. It is also obvious, at all levels of society, that there were times when women had to take charge of estates and run holdings because their menfolk were away on business, at war or otherwise detained, or the heir was a minor or a lunatic and thus legally unfit. It has become very easy to let the stereotype of the genteel Victorian married lady, who did not sully her hands with real work, colour our view of women of the past. It seems that these women either had to get on with the hard work themselves, or employ and instruct a steward or agent to ensure that a livelihood continued to be earned.

Hampshire was chosen for study since it is, and always has been, a largely rural county, characterised by numerous substantial estates, both aristocratic and institutional. Estates such as that of the Dean and Chapter of Winchester furnish a great deal of material relating to tenancies and rents, with runs of ledgers from the fourteenth to the nineteenth centuries, and rentals and court rolls covering the period 1600 to 1800 . Although there are major ports in Portsmouth and Southampton, and a number of market towns, agriculture has always been very important, with a number of related industries, such as market gardening, the dairy industry and wood working. It could be argued that the county's rural nature, with a lack of widespread industrial alternative occupations, led its paternalistic landlords to ensure some continuity of occupation and employment.

At the local administrative level of the manorial court, which governed the bulk of tenurial and agricultural matters, little gender discrimination appears to have taken place. The bulk of later manorial documentation in Hampshire concerns itself with land transfers, particularly of 'copyhold' or 'customary' lands. Copyhold land was held by copy of court roll, generally for three lives that could be renewed on payment of a fine, or by inheritance and was held by women of all types of marital status. Leasehold land was also held by women, mainly by spinsters and widows. This was land held at a fixed rent for a fixed term (often twenty-one years in Hampshire), and treated as not subject to descent by primogeniture. These surrenders of, and admissions to, property are best used in conjunction with survey and rental material where it exists since, as time went on, large landowners converted copyhold land to leasehold or freehold land. It is not, therefore, always possible to ascertain what proportion of the land let to tenants copyhold land represented, unless there is access to other material indicating the extent of freehold and leasehold land. Nevertheless manorial material is extremely useful in the calculation of the ratios of men to women as numbers of tenants. The problems of extent can be answered partly through a study of the tithe material.

The wording of stewards' instructions, surrenders and admissions rapidly became formalised in most manors and were an expression of what was expected of the transaction. It soon becomes clear when studying these documents that tenants were not categorised according to gender. The wording generally includes some indication of the next person to be admitted to the property, along the lines of 'to the use and behoof of [gap left for name to be inserted] and his [or her] heirs and assigns ...'. These documents were, for a long period, handwritten; in the early eighteenth century, there was a move towards 
pre-written or pre-printed forms. In the manor of Exton held by the Dean and Chapter of Winchester, these documents have this format, with an ' $\mathrm{H}$. . .' allowing for the insertion of either 'his' or 'her', showing that there was no pre-supposition as to gender. ${ }^{13}$ There is no reason to believe that the forms used by the manor's steward were in any way unusual.

While male and female tenants were treated in much the same way by the manorial courts, it cannot be said that the courts were immune from the effects of the legal system. It is clear from the wording of entries that married women were tenants in their own right, illustrating a practical redress to coverture. In a run of court admissions and surrenders for the manor of Barton, dating from 1597 to 1852, married women are specifically mentioned eleven times, generally in such terms as 'Elizabeth Trinder the wife of John' or 'Elizabeth Thorn wife of Rechab'. ${ }^{1+}$ At Highclere, where the Earl of Carnarvon was lord of the manor, between 1962 and 1722 there are 36 entries of transactions involving married women. ${ }^{15}$

The effects of coverture are reflected in the wording of manorial documents. Land brought to the marriage is signalled by wording such as 'in the right of his wife...', and the property may have been transferred before the solemnisation through a surrender to the lord of the manor. The surrender might be made by the spinster herself. On the 17th July, 1707, in the Dean and Chapter of Winchester's manor of Crondall, Priscilla Paynter, the eldest daughter and heir of George Paynter, in consideration of her forthcoming marriage with Thomas Rawlingson of Odiham, surrendered 'one messuage and five acres of lands called Southworth, and one messuage with customary lands, also Warncroft, being parcel of the customary lands of George Paynter, and also all the other copyhold lands of Priscilla to the behoof of Thomas Rawlingson after the solemnisation of the marriage'. ${ }^{16}$ It is clear that she is giving up all the land she was entitled to for the benefit of her marriage, and to secure a living for her future family.

The parents of the intended bride also undertook this service. In the same series of Crondall surrenders, we find in 1740 that James Clarke surrendered land in consideration of the forthcoming marriage of his son John with Elizabeth Goody, and Elizabeth Wooldridge surrendered land on the 6th April, 1688, to the behoof of her daughter Rachell, the intended wife of Robert Okehurst. ${ }^{17}$

When land acquired in this way was given up by the husband, it was customary for his wife to be questioned separately by the steward. This was not a new practice, having two purposes, firstly to ascertain that she was not being made to surrender it under duress, and also to protect buyers of land from widows' claims of dower and free bench. At Crondall on the 16th June, 1688, Margaret Lamon was 'secretly examined of her good will and free and spontaneous consent'. For this transaction. the steward, Philip Williams, charged the Dean and Chapter $8 \mathrm{~s}$. $8 \mathrm{~d}$., noting that if a man and his wife joined in a surrender, he would take it as one surrender only, exclusive of this fee. As with any such phrase in manorial documentation, it is difficult to know if and when it became purely formulaic. However, it does indicate that there was a real concern that married women should not be forced to give up land against their will, though it is not clear even then, how freely a woman could express dissent to a steward in confidence. It may be that, in those cases where the woman did not agree, the surrender did not get as far 
as the court. It is also possible that women may have been forced by their husbands to lie to the steward.

The manor of Westbrooke, Alton, in the late eighteenth and early nineteenth centuries, provides an illustration of the use made of this convention. A court book dating from 1789 deals mainly with trespass cases and a form of recovery which seems to be characteristic of the manor. ${ }^{18}$ These were carried out under the aegis of a Writ of George the Third, in which the defendant should 'without delay and according to the custom of the said manor ... do full right to [the suitor] concerning [description of the land] of which [the second party] deforceth him that we hear no more complaint thereof for want of right', accompanied by a monetary payment to those surrendering the land. Of the 72 entries from 1789 to 1830,68 include secret examinations of the wives, and seven cases where more than one wife (presumably sisters or sisters-in-law) was quizzed. In one case, the suitor was a woman, Ann White, in 1802. These figures indicate how important women's holding of land might be in a particular manor at a particular time.

There is a noticeable trend in the early eighteenth century in some manors for tenants to undertake mortgage surrenders to raise money on the lands, and it is clear that women were as likely as men to mortgage their copyhold lands. In the manor of Highclere during the period 1777 to 1796 , the records include fifty mortgage surrenders, of which three are by couples (presumably where the land is held in right of the wife), and two by women. In one court roll covering the several manors held by the Dean and Chapter of Winchester dated 1728, there are twelve mortgage surrenders, of which one is by a man to a woman, four are by couples where the wife was first solely and secretly examined, and one by a woman. ${ }^{19}$ As with land tenure itself, no discrimination appears to be in operation against female tenants in the matter of raising money against their holdings.

While many historians consider that England was largely a country of landlords and tenants, ${ }^{20}$ and the customary structure allows for the relatively straightforward discovery of women landholders, the work of Reed and Howkins suggests that there was a large number of independent family producers in agriculture who are by no means as fully recorded. ${ }^{21}$ While these producers may have occupied only a small proportion of the available land, undoubtedly women were represented here also. Reed concludes from the 1851 census that "only $6.5 \%$ of "farmers" and "graziers" in the south-east were women, and this was probably more or less true of these "farmers" who only used family labour'.22 Some allowance should be made in my own figures for this shadowy but substantial minority.

Women tenants may sometimes have formed up to twenty five per cent of all tenants over long periods. Table 1 . shows the results from six manors, the first four of which belonged to the Dean and Chapter of Winchester, of analysis of surrenders and admissions spanning the period 1567 to 1852 . For the purposes of analysis, instances where women are mentioned are added to instances where they are part of couples, since in these cases, the land is often held in right of the wife.

Rentals show that customary tenants, in particular, were often widows. A series of court rolls from the manor of Highclere and Burghclere includes details of the freeholders, copyholders and leaseholders from the 1690 s to the $1740 \mathrm{~s} .{ }^{23}$ In one case, a freeholder is a woman, but women are more often included in the copyholder category, or sometimes 


\begin{tabular}{lcc}
\hline $\begin{array}{l}\text { Table } 1 \\
\text { Percentage of Women Landholders in selected manors in Hampshire } \\
\text { Manor (with Lord) }\end{array}$ & $\begin{array}{l}\text { Total number of } \\
\text { transactions }\end{array}$ & Women landholders \\
& & $17.97 \%$ \\
Dean and Chapter: & 1,246 & $14.96 \%$ \\
Barton (1597-1852) & 147 & $18.09 \%$ \\
Chilbolton (1627-1849) & 967 & $17.23 \%$ \\
Crondall (1567-1820) & 470 & \\
Exton (1683-1852) & & \\
Earl of Carnarvon: & 1,773 & $19.51 \%$ \\
Highclere (1690-1726) & & \\
Richard Howard/Sir Brook & & \\
Watson: & & \\
Greywell (1788-1878) & 42 & \\
Source: Winchester Cathedral Archives, T2A/2/1, T2A $3 / 1 ;$ \\
HRO 15M52/27-30, 15M52/33, 10M57/M3. \\
\hline
\end{tabular}

in a separate category entitled 'customary tenants'. In 1692, of fifty-four copyholders, sixteen were widows, in 1695 there were eleven widows among thirty-six copyholders, and in the $1690 \mathrm{~s}$, all the customary tenants were widows.

The Books of the Common Seal of the Dean and Chapter of Winchester record the legal transactions involved in leasing land, and many of the manors held by the Chapter were leased for the term of twenty-one years. The leases deal with a large range of acreages, from the manors with their associated lands to cottages with their curtilages. In a preliminary study of the period 1671 to 1677 , the women holders form 15.3 per cent of the total leaseholders, a figure much in accordance with the copyhold tenancies. ${ }^{24}$ It may be possible to find comparable material in manors situated on the extensive chalklands in the north of the county to ascertain whether, in these areas, there was a greater tendency of major landholders to sublet their land to substantial tenants, and whether these were more likely to be male.

The documentation resulting from the Tithe Commutation Act of 1836 allows one to quantify exactly what land was held by women in a parish after centuries of transfers and reorganisation on a small and day-to-day scale. Almost all parishes in England were surveyed and mapped during the late 1830 s and early 1840 s, and it therefore provides a means to assess the geographical patterns of female landholding. ${ }^{25}$ Further, the apportionments show both ownership and occupation, and this allows some disentanglement of the two, something not always possible in other kinds of documentation. The holdings of individual women at the time of the tithe surveys, whether as owners or occupiers, have been added together, and expressed as a percentage of the total of tithable land in any parish. Although the tithable total does not always represent the total acreage of a parish, the apportionments are at least consistent in their approach to measurement.

In Hampshire, of the total of 279 parishes dealt with by the Tithe Commission, forty-three or 15 per cent had no women owners or occupiers. Such parishes were sometimes in the hands of one single, often aristocratic owner, with a small number of tenants holding large areas of land. Because the tithe is just as much of a 'snapshot' as 
any other documentation of this kind, it is quite possible that at other times these single owner parishes would be in the hands of women, generally widows. There is one example of this in Hampshire tithe apportionments, that of Anne Hussey, who held 276 acres, 3 roods and 22 perches (acreages hereafter notated as in 276-3-22) in Upeldon, which was all the tithable land in that parish. Dame Jane Mildmay, who was a widow for fifty years, held 561-0-35 herself as an owner-occupier in Dogmersfield parish at the time of the tithe, rented 20-1-37, and let a further 1,067-0-24 to tenants, representing 95.41 per cent of the total 1,728-1-28 of tithable land. Similarly, at Barton Stacey, Mary Wright Henniker Wilson owned and occupied 302-2-09 herself, and let a further 2,378-1-19 to tenants. This was 60.1 per cent of the total tithable land in the parish. Ovington is an interesting example where the largest holding, of 97-3-37, was owned and occupied by Baroness Elizabeth von Zandt and the Earl of Northesk. They let a further 2-1-29 to tenants, and the other 18-3-06 of tithable land in the parish was let to a female tenant.

Where a female was not the main owner and occupier, women were sometimes the tenants of large holdings. In South Charford, Sarah Rooke renting from Sir Charles Hulse held 525-0-35, making her the largest single tenant, with 63 per cent of the tithable land in that parish. Susannah Batt held 606-0-06 under Henry Pierrepoint in Penton Mewsey, with a further 68-1-39 of other land either owned by herself or rented from other owners, giving her 70.36 per cent of the tithable land.

Table 2

\begin{tabular}{lcc}
\hline \multicolumn{3}{l}{$\begin{array}{l}\text { Women's landholding in all Hampshire parishes } \\
\text { surveyed under the Tithe Commutation Act of 1836 }\end{array}$} \\
$\begin{array}{l}\text { Percentage of } \\
\text { Total Holdings }\end{array}$ & $\begin{array}{l}\text { Number of } \\
\text { Parishes }\end{array}$ & $\begin{array}{l}\text { Percentage of All } \\
\text { Parishes }\end{array}$ \\
in a Parish & & \\
0 & 43 & 15.41 \\
$0.001<1$ & 63 & 22.58 \\
$1<5$ & 64 & 22.93 \\
$5<10$ & 38 & 13.62 \\
$10<15$ & 28 & 10.03 \\
$15<20$ & 15 & 5.37 \\
$20<25$ & 4 & 1.43 \\
$25<30$ & 8 & 2.86 \\
$30<35$ & 5 & 1.79 \\
$35<40$ & 3 & 1.07 \\
$40<45$ & 1 & 0.35 \\
$45<50$ & 1 & 0.35 \\
$60<65$ & 2 & 0.71 \\
$70<75$ & 1 & 0.35 \\
$95<100$ & 3 & 1.07 \\
Total & 279 & \\
Source: 21 M65/F7 series of Tithe Apportionments and \\
Maps, 1830 s, 1840 s and 1850 s, Hampshire Pecord Office
\end{tabular}

Women's holdings, whether as owners or occupiers are illustrated in Table 2, and fall predominantly in the 0.001 to 20 per cent range, with 208 of the 236 parishes with some female landholders within this band. The other 28 parishes are spread between 20 and 
100 per cent, with three parishes where women owned or occupied between 95 and 100 per cent. ${ }^{26}$ These concentrations accord well with the percentages found in manorial documentation.

Those parishes without any women landholders form a prominent band in the central northern part of Hampshire, and those with 1 per cent and under are concentrated in the northern half of the county. The band of between 1 and 5 per cent is widely represented throughout Hampshire, but is most noticeable on the chalklands of the north west, an area of large arable farms concentrating on the growing of grain, and most likely to be in the hands of substantial (and mostly male) tenants. Holdings representing between 5 and 10 per cent of tithable land appear to be distributed in the south and east of the county, where the heathy soils and the predominance of pasture allow for smaller individual holdings, and this is where the characteristic 'squatter' settlements and encroachments are to be found. A look at the enclosure award of 1814 for the Forest of Bere, in the south east of the county, and taking in several parishes, shows the highest number of women allottees of any award in Hampshire, with 61 out of a total of $401 .^{27}$ The mean size of allotments is 3.73 acres, although the majority are actually only about one acre or less in size. This is very much in accordance with the idea of the widow with her cottage and acre plot, and the enclosure material provides useful corroborating evidence for the tithe material.

Parishes where 10 to 15 per cent of land was held by women are located around the periphery of Hampshire, but in the higher bands, there are too few examples for a pattern to be detected. The fact that the concentration of women's landholding at the tithe is between 0.001 and 20 per cent suggests that there is some substance in the argument that this is the 'background' level, and that the few examples of much higher percentages are really 'snapshots' of the kind of holding resulting from widowhood, and are thus much less predictable. Some of these examples probably exist in every county at any given time.

The tithe data also allows the relationships between women as owners and occupiers to be identified. Holdings were put into categories as follows:

Female owner and occupier

Female owner letting to female relative

Female owner letting to unrelated female

Female owner letting to male tenant

Female owner letting to related male

Male owner letting to female relative

Male owner letting to unrelated female

A further distinction was made, related to the size of holdings. A threshold of five acres was identified as a point above which land might be thought of as useful for serious cultivation, in the sense of probably being large enough to allow for a subsistence living to be made from it. All women's holdings, whether as owners or occupiers, larger than five acres were added together and expressed as a percentage of the total of land held by women in any particular parish. 
From the data collected from Hampshire, it is clear that women tended to be owner/occupiers, to let their land to male tenants or to rent their holdings from male landlords. No parish had women holding in all seven categories at the tithe, and there were only seven instances where women let to apparently related females, with only one such owner in each parish. ${ }^{28}$ It is, of course, not possible to know whether all letting transactions between relatives have been identified, once again because of the effect of coverture through the English custom of women's name changes on marriage. There appear to be thirty-seven instances where women let their land to male relatives, and at Hound and South Warnborough these lettings represent 100 and 94.7 per cent of the female transactions. Women letting to other women seems to be more common, with 28 per cent of parishes showing examples of this. Two thirds of the parishes had examples of women renting from men. In some parishes, women rented large plots from male landowners, such as at Bentworth where two women rented over 90 per cent of the 307 acres shown as being occupied by females. Similarly, at Faccombe three women occupied over 99 per cent of the 747 acres owned or rented by women.

In 68 per cent of parishes there are plots over five acres owned or occupied by women which would allow for 'farming' in some sense. Where these plots exist, they form the bulk of all landholding by women. Of the 32 per cent of parishes where five-acre plots are not found, either there are no female landholders at all, such as at Ashley, Buckholt, Hartley Mauditt and East and West Tytherley, or women's plots are all very small, often not even the traditional cottage and an acre. At Wickham, there were twenty female holders with almost eighteen acres between them, at Appleshaw five holders with 1.54 acres and at Crawley four owners with 0.7 of an acre.

There are three parishes where the female 'farmers' hold under 50 per cent of women's land: 35.5 per cent at Brockenhurst, 47 per cent at New Alresford and 49 per cent at Bedhampton. Otherwise, the majority of parishes have totals over 80 per cent, and thirteen parishes exhibit totals of 100 per cent. It would appear that women who held land were actively engaged in working their land, either themselves or through the labour of others.

The tithe apportionments illustrate the widespread nature of women's landholding in Hampshire. Enclosure awards, though rather more scattered temporally, confirm this female presence, as do land tax assessments. Curiously, by the time of the next great survey of landholding, the Returns of Landowners in 1875, women have largely disappeared. ${ }^{29}$ Although this survey is seriously flawed, and it and the tithe are not strictly comparable (for instance, the Return gives the parish in which the holder resides, but not the place where his or her land is situated), there does seem to be a marked diminution in the number of women holders at this later date. Undoubtedly, with greater employment opportunities, many women will have given up the struggle to make a living out of a cottage and a small plot of land, especially once common rights were widely extinguished in most parishes. Women were probably as likely as men to sell their small plots of land for building at a time of urban expansion.

Since female landholders appear to have been treated no differently from male landholders in the courts and at the tithe, it is possible to argue that they cultivated and used their land in the same way that men did. There is nothing to suggest otherwise. 
It is likely that the constraints of custom and agricultural techniques until recent times dictated that all landholders were limited in the way that they could farm their land. Indirect sources illustrate this. Jones commented that an estate agent at New Down Farm at Stratton (Micheldever) noted in 1799 that 'the tenant is too much disposed to sow the land in a greater proportion than it ought to be: it would pay her better if less of the Down land were in tillage and more of the poorest parts of the farm either in sanfoin or laid down with artificial grasses. ${ }^{30}$ This kind of disquiet had been widely expressed in a time of soaring grain prices. Women like Elizabeth Fleming, who ran the family estate in the early nineteenth century, made her presence felt through vigorous use of her steward. This is reflected in the clauses she inserted into leases, indicating that she kept a close eye on her tenants. ${ }^{31}$ Although it has been argued that there might be an inclination to favour male tenants (who could be induced to vote as the landlord wished), and that female tenants represented a wasted vote, I have not yet discovered any evidence from the Hampshire material that such considerations mitigated against women being allowed to take tenancies. ${ }^{31}$

Scrutiny of manorial and tithe documentation makes it obvious that the strictures of coverture were circumvented on a practical level. Coverture as a servant of primogeniture was simply too harsh in a world of high infant mortality and short life expectancies, where parents of all classes were forced to find a living for their offspring, or consign them at the lower end of the social scale to the rigours of the landless labourer's life, with no prospect of marriage or a family life of their own. In our comfortable world, where we seem able to manufacture certainties, it is hard to imagine the tenuous hold that ordinary people had on their means of subsistence. As has been well documented elsewhere, the lot of the landless peasant or the small cottager was a hard one at the best of times.

Since it appears that so little gender discrimination took place at the manorial level, it seems that the major landholders appreciated the flexibility of female inheritance as a means of countering the rigidity of coverture where scarce resources were required to provide livings for many people. Aristocratic and great landowners had at times to resort to female inheritance themselves because of demographic failure. Some families were especially troubled with the failure of the male line, and had to utilise the custodianship of widows, along with name-changing as a means of keeping estates together. A good example in Hampshire is the Fleming family of North Stoneham, dogged by childlessness. Twice in one century, the seat and estate had to be passed to a collateral branch of the family, with the inevitable adoption of the name Fleming. In the 1740s, Richard Fleming's widow took part of the estate of her new husband Sir Francis Pyle as a life interest, and by 1800 Elizabeth Fleming was looking after the estate as the widow of John Fleming (who was born John Willis).

As Searle has demonstrated, in feudal and post-feudal times, landlords felt obliged to exercise control over the marriage of their female tenants in order to be able to approve males coming into their manors. With short life expectancies, it was inevitable that land should pass to the women of the family at times. Primogeniture is an expensive habit for the relatively poor family. Minor landholders' wills and rentals show clearly that heads of families were keen to provide a living for all their children if possible, giving 
girls as well as boys small plots of land. If customary and manorial tenants could provide livelihoods for their offspring, the landlord would have a pool of potential labour with a real and personal interest in their land and his, and fewer calls upon the poor rates. Tenants were potentially more malleable, especially through the manorial courts, than landless labourers.

It would appear that women formed up to one fifth of all tenants on most manors at any time before about 1850 in Hampshire. Women, particularly widows, were at times in control of parishes and manors. Erickson argues that widows were really rather powerful, because of their many opportunities to administer estates, and their automatic right to one third of their husband's assets. Further, she argues that their economic position was gradually eroded to counterbalance this underlying power. ${ }^{33}$ However, the presence of women owners and occupiers throughout manorial and tithe records suggests that this erosion came through the actions of ecclesiastical courts, and that the manorial courts tended to uphold the widow's life interest (however strictly limited this sometimes was) in her late husband's land.

It is possible that undiluted primogeniture at all levels of society would never have worked in the demographic conditions of the past. Peasant proprietors had to be practical, and probably had to accept that the passage of land intact from one generation to another was not for them. Intact transmission may not even have been a goal for most small landholders. The customary structure, with its assumption that women, particularly widows, would take over a holding where necessary, and its acknowledgement of the rights of married female holders even when copyholds were nominally held by men, allowed for the relief of the stresses engendered by the competing demands of coverture, primogeniture and demographic failure. Even when manorial courts had stopped directing husbandry and had largely abandoned scrutiny of customary practices (generally by the mid seventeenth century in Hampshire), women's rights as landholders were still being upheld. This continued into the nineteenth century, when, in a sense, common law through reform caught up with customary law in terms of property rights for women. The evidence from Hampshire that I have collected suggests that up to 20 per cent of landholding by women provided the means of passing on holdings as completely as possible while at the same time providing a living for family members under the customary structure. Women's landholding contributed to the continuance of stability for both owner and tenant, and empowered them in the face of strictures under which they would otherwise be rendered legally non-existent.

\section{Notes}

1. Some examples are L. Bonfield, "Marriage Settlements and the "Rise of the Great Estates": the Demographic Aspect' Economic History Review, 32 (1979), 483-93; Bonfield, Marriage Settlements, 1601-1740: The Adoption of the Strict Settlement (1983); C. Clay, 'Marriage Inheritance and the Rise of Large Estates', Economic History Review, 21 (1968), 508-18; H.J. Habbakuk, 'The Rise and Fall of English Landed Families, 1600-1800', Transactions of the Royal Historical Society, 29 (1979), 187-207: 30 (1980), 199-221:199-221; 31 (1981), 195-217.

2. This is an expanded version of a paper given to the 16th session of the European Standing Conference for the Study of the Rural Landscape at Turin in September, 1994. I would like 
to thank Dr. John Chapman, Dr. Keith Snell and an anonymous referee for their very helpful and constructive comments.

3. J.H. Baker, An Introduction to English Legal History (London, 1979), p. 232. For a very full discussion of the legal position of married women in relation to property see L. Holcombe,

Wives and Property: Reform of the Married Women's Property Law in Nineteenth-Century England (Toronto \& Buffalo, New York, 1983), particularly chapter 2, pp. 18-36 and chapter 3, pp. 37-47, and also S. Staves, Married Women's Separate Property in England 1660-1833 (Cambridge, Mass. 1990).

4. A.L. Erickson, 'Common law versus common practice: the use of marriage settlements in early modern England', Economic History Review, 43 (1990) 21-39.

5. E. Searle, 'Seigneurial control of women's marriage: the antecedents and function of merchet in England', Past and Present, 82 (1979) 3-43.

6. J.H. Baker (ed.), An Introduction to English Legal History, (London, 1979).

7. E. Searle, 'Seigneurial control' pp. 30-31. Brand and Hyams ('Seigneurial Control of Women's Marriage', Past and Present, 99 (1983), 123-33) take issue with Searle on the origins of merchet and prefer to see it primarily as a payment on marriage indicating villein status for the peasantry, though they do not dispute the inheritance issues in the honorial courts. Rosamond Faith (also in 'Seigneurial Control of Women's Marriage', Past and Present, 99 (1983), 133-48) inclines to the same view, but Searle's research highlights the tensions experienced on the practical level between the demands of primogeniture, the effects of common law on women's marriage and property, and the fluctuations of demography.

8. P. Franklin, 'Peasant Widows' "Liberation" and Remarriage before the Black Death', Economic History Review, second series 39: 2 (1986), 186-204. For a fuller discussion of the workings of free bench, see J. Bennett, Women in the Medieval Countryside: Gender and Household in Brigstock before the Plague (Oxford, 1987). Richard Smith considers peasant jointures and deathbed transfers as the main source of security for medieval widows and as a means of dealing with the problems of patriarchy in J. Kermode (ed.), Enterprise and Individuals in Fifteenth-Century England (1993).

9. J.C. Russell, British Medieval Population (1948), p. 64; J.Z. Titow, English Rural Society, 1200-1350 (1969) p. 87; R.H. Hilton, The English Peasantry in the Later Middle Ages, 1974, ch. 6; J.F. Willard, Parliamentary Taxes on Personal Property, 1290-1334 (1934)., pp. 168-9; the last figure was calculated by Franklin from Sir T. Phillips, Gloucestershire Subsidy Rolls, I Edruard III. A.D. 1327.

10. A.L. Erickson, Women and Property in Early Modern England, (London, 1993).

11. A.L. Erickson, 'Common law versus common practice: the use of marriage settlements in early modern England', Economic History Review, 43 (1990), 21-39.

12. J. Thirsk, 'The Common Fields', Past and Present, 29 (1964).

13. $W$ (inchester) $\mathrm{C}$ (athedral) $\mathrm{A}$ (rchives) $\mathrm{T} 2 \mathrm{~A} / 3 / 1$ and $\mathrm{T} 4 / 2 / 6 / 35$ (interim catalogue) Exton manorial court rolls $1683-1852$.

14. WCA, T2A/2/1/6-21 and T4/2/6/30-6.

15. H(ampshire) $\mathrm{R}$ (ecord) $\mathrm{O}$ (ffice) $15 \mathrm{M} 52 / 27-29$.

16. WCA T2A/2/1/66-100, manor of Crondall surrenders, 1650-1870.

17. WCA T2A/2/1/66-100, 1650-1870.

18. HRO $4 M 51 / 61$.

19. WCA T4/2/6/32.

20. For example, E.J. Hobsbawm, Industry and Empire (London, 1969), p. 98.

21. M. Reed, 'The Peasantry of Nineteenth-Century England: a Neglected Class?', History Workshop fournal, 18 (1984), 53-76; M. Reed, 'Nineteenth-Century Rural England: A Case for "Peasant Studies"?', Journal of Peasant Studies, 14 (1986-7), 78-99; A. Howkins, 'Peasants, Servants and Labourers: The Marginal Workforce in British Agriculture, c.18701914', Agricultural History Review, 42 (1994), 49-62.

22. M. Reed, 'The peasantry', p. 59. 
23. HRO, 15M52/27-30, 33 .

24. WCA, L(edger) B(ooks), XII, 18-19, 1671-18. In this preliminary survey, 10 out of the total 65 leaseholders were women, either by themselves or with others.

25. See R.J.P. Kain and H.C. Prince, The Tithe Surveys of England and Wales, (Cambridge, 1985).

26. These are Dogmersfield, Upeldon and Ovington.

27. These are Soberton, Hambledon, Catherington, Blendworth, Bedhampton, Kingston, Portsea, Farlington, Wymering, Widley, West Boarhunt, Portchester, Wicor, and Wickham. The award is HRO Q23/2/11/1.

28. The instances are in Faccombe, Fareham, Farringdon, Hamble, Hurstbourne Tarrant, Kingsclere and Wickham.

29. Return of Owners of Land, Vol. 11, Part I, 1875, HMSO.

30. E.L. Jones, Agriculture and the Industrial Revolution, (Oxford, 1974).

31. See, for instance, HRO 102M71/E43, dated 1806.

32. In fact, the male minor tenants I have been looking at may not have been entitled to vote anyway. In most cases the properties concerned were too small to meet the copyhold and leasehold qualifications. For a discussion of the question of rural deference, see T.J. Nossiter, Influence, Opinion and Political Idioms in Reformed England: Case Studies from the North-East (1975).

33. Erickson, Women and Property, pp. 223-36. 